http://dx.doi.org/10.18778/7525-902-5.02

\title{
Liberia ma kobiece rysy: Ellen Johnson-Sirleaf jako pierwsza w historii prezydent w Afryce
}

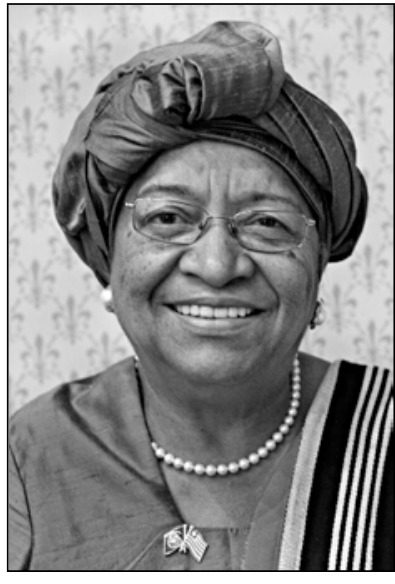

Na przełomie 2005/2006 roku, na kontynencie uznawanym za kolebkę ludzkości zaszły rewolucyjne zmiany. Choć przełom nie dotyczy zmian klimatycznych $\mathrm{w}$ dosłownym tego słowa znaczeniu, to metaforycznie rzecz ujmując, afrykański klimat polityczny wszedł $\mathrm{w}$ fazę potężnych przemian. Afryka, która jest najbardziej rozdrobniona pod względem ilości państw położonych na jednym kontynencie, jest zdominowana przez rządy „silnej ręki”, przez rządy o charakterze patriarchalnym (Wamue-Ngare i Njorge 2011). Sytuację w kraju afrykańskim, w którym władzę najwyższą przejmuje kobieta, bez wahania można określić mianem sytuacji rewolucyjnej, a do takiej doszło w 2006 roku w Liberii.

Liberia spojrzała na świat kobiecymi oczami po zwycięstwie Ellen Johnson-Sirleaf w demokratycznych wy- 
borach prezydenckich. Zapisze się ona jako pierwsza kobieta w historii Afryki, której udało się wygrać wybory prezydenckie z mężczyzną, w zaciętym wyścigu po władzę. To niebywałe zwycięstwo odniosła dwukrotnie, najpierw w 2005 oraz powtórnie, w 2011 roku. Jej hasła wyborcze zachęciły tłumy do głosowania, zwłaszcza rzesze uciskanych i dyskryminowanych. Pierwszy slogan wyborczy głosił: „Ellen, to nasz człowiek”. Drugi został zaprezentowany w kilku odsłonach, będących skomplikowaną grą językową. Hasło: „Monkey is still working, baboon wait small" wykorzystywało dialekt klas niższych, znany tylko Liberyjczykom i tylko dla nich w pełni zrozumiały. Pod postacią kontrastowego zestawienia „pracującej małpy” z korzystającym z jej wysiłku „pawianem" ukazano panującą w Liberii niesprawiedliwość społeczną. Pani prezydent wzywała do tego, by pozwolić jej trzymać ster w dalszym ciągu, by „nie zmieniać pilota, skoro lot trwa dalej" (jak brzmiało kolejne hasło wyborcze tej kampanii). Wygrywając po raz pierwszy dawała nadzieję, że dzięki nowej, innej od stosowanej przez poprzedników polityce, odbuduje zniszczoną wojną domową Liberię. Druga wygrana potwierdziła skuteczność rządów kobiety prezydenta, która przejęła władzę w kraju pozostawionym przez mężczyzn w tragicznym stanie.

\section{Liberia - ojczyzna noblistki}

Gdyby wskazać na mapie najstarszą republikę w Afryce, to z pewnością od razu należałby skierować wzrok w stronę jej zachodnich krańców. Sam kontynent można porównać między innymi do znaku zapytania (niepełnego, bowiem bez kropki) albo do złamanego 
serca, jak czyni to afrykańska piosenkarka, Imany, w utworze "Shape of a Broken Heart”. W zachodnim zakamarku tego pękniętego serca znajduje się swego rodzaju ewenement na kontynencie - Liberia. Przypadek tej republiki, niewielkiej pod względem powierzchni oraz populacji, jest o tyle niezwykły i zastanawiający, że w zamyśle miała być rajem na ziemi dla wyzwolonych, to jednak przez większość czasu swego istnienia raczej stanowiła ziemskie piekło.

W wielkim skrócie, z kart liberyjskiej historii wiadomo, że w XIX wieku Amerykańskie Towarzystwo Kolonizacyjne zaczęło wysyłać oswobodzonych czarnych niewolników z USA do Afryki. Na tym terenie miało powstać społeczeństwo, będące spełnieniem marzeń, czyli kraj ludzi wolnych i niezależnych. Etap migracji przyniósł osadników, zaś formalny - w 1847 roku uchwalenie konstytucja Republiki Liberii. Łacińskie słowo liber na zawsze związało tę republikę z pragnieniem osiągnięcia pełnego wyzwolenia ludności czarnej spod władzy innych czarnych i dążeniem do wolności różnych grup społecznych, również kobiet zniewolonych przez radykalny patriarchalizm (Woodson 2008: 146).

Jako pierwsze niepodległe państwo w Afryce - kraj wymyślony przez orędowników wolności, Amerykanów - Liberia wzorowała swoją flagę na amerykańskiej, zaś amerykański system demokratyczny pozostał nigdy nieosiągniętym wzorem do naśladowania. Oddając cześć prezydentowi Stanów Zjednoczonych, Jamesowi Monroe'mu, stolicy Liberii nadano nazwę Monrowia. Od początku nie zadbano o równość, i choć Liberia powstała jako niepodległe państwo, założone przez wyzwolonych w Ameryce czarnych niewolników, którzy zdecydowali, by wrócić do Afryki, ci ostatni, mimo że sami doświadczeni przez „rządy silniejszego”, białego człowieka, posłużyli się mechanizmem podporządkowania sobie 
rdzennej ludności. Pierwsi osadnicy określają się mianem Amerykanoliberyjczyków, stanowiąc obecnie tylko 5 procent populacji, reszta - to ludy tubylcze, czyli 95 procent całego społeczeństwa. Szybka kolonizacja pozbawiła lokalną populację praw, podobnie jak stało się to w Republice Południowej Afryki w okresie apartheidu. Owszem, narodziła się demokracja, lecz tylko w określonych granicach, mianowicie wewnątrz społeczności Amerykanoliberyjczyków i ich potomków. Gorsi, skolonizowani, czyli pozbawieni prawa głosu miejscowi, traktowani jak mniejszość, zostali zmuszeni do przetrwania fazy kolonizacji.

Kiedy utopistyczna idea stworzenia w Liberii raju na ziemi objęła tylko część ludności zamieszkujących tę republikę, w zasadzie oznaczało to, że wykluczeni z tejże koncepcji autochtoni zostali wciągnięci w wieloletnie konflikty, do czego dołożył się wyzysk i okrucieństwo "grup trzymających władzę”. Liberyjczycy, czyli wszystkie czarne społeczności, jedne zdane na drugie, umacniały podział na wyzyskiwanych i wyzyskujących, praktycznie bez konsekwencji ze strony sił zewnętrznych; przynajmniej nieoficjalnie.

W tym miejscu należy wspomnieć o jednym $\mathrm{z}$ najcięższych w historii Liberyjczyków okresie dyktatury Charlesa Taylora, prezydenta Liberii w latach 19972003. Startując w wyborach, przygotował wymowne i mocne hasło: „Zabił moją mamę, zabił mojego tatę, ale i tak na niego zagłosuję". I jak się okazało, zagłosowało na niego 75 procent zastraszonej ludności. Wybrali oni bezwzględnego mordercę, któremu udało się wyszkolić armię wiernych poddanych, także tych najmłodszych, likwidujących lub unieszkodliwiających każdego, kto choćby mrugnięciem sprzeciwił się poleceniom wydawanym „z góry”. Taylor, zwany rzeźnikiem, posiadał 
zasoby finansowe ze sprzedaży diamentów oraz zasoby militarne $\mathrm{w}$ postaci postsowieckiej broni i bez trudu przyszło mu prowadzenie wojny domowej w rodzinnej Liberii oraz w sąsiedniej Sierra Leone. Metody sprawowania władzy opierały się na terrorze, szantażu, okaleczaniu, najczęściej obcinaniu ręki lub jej kawałka i wymuszaniu posłuszeństwa, np. poprzez zabójstwo własnych członków rodziny. Na porządku dziennym odbywały się gwałty na kobietach, nie mogących nigdzie zgłosić się jako ofiary przemocy (Sherman 2010: 320-322)

O sytuacji „bez wyjścia” opowiada film pt. Liberia - podróż do kraju wojny (Liberia - An Uncivil War, 2004), w reżyserii Jonathana Stacka, będący dokumentem pokazującym ludzkie zdziczenie, nie mające żadnych ograniczeń, nawet wiekowych, np. przemawiające do wyobraźni obrazy przedstawiające armię dzieci-zombie, odurzonych narkotykami i alkoholem. Jedynym obowiązującym prawem było prawo do popełniania zbrodni. Innym filmem doskonale ukazującym „apokalipsę na ziemi" jest dokument w reżyserii Erica Straussa i Daniele Anastasion, zatytułowany Nagi generał (The Redemption of General Butt Naked, 2010). Anty-bohaterem filmu stał się Joshua Milton Blahyj, który zasłynął z barbarzyńskich zbrodni jako dowódca „nagiej armii”, której żołnierze ubrani byli tylko w buty oraz narzędzia wojenne. Joshua Milton Blahyi jest obecnie czynnie działającym pastorem. Z kolei liberyjską sprawę pokojowej walki o prawa, kobiet, zrzeszonych dzięki wspólnym wysiłkom oraz niestrudzonej, młodej działaczce - Leymah Gbowee, naświetlają Abigail Disney oraz Ginia Reticker w filmie Idź diable precz (Pray the Devil Back to Hell, 2008). Jednak o organizacji Women of Liberia Mass Action for Peace, która również doprowadziła do elekcji Ellen Johnson Sirleaf szerzej mówi Izabella Penier w kolejnym rozdziale. 
Tuż po zakończeniu wojny sytuacja kobiet była nie tylko tragiczna, ale i beznadziejna. Utrzymywało się bestialskie traktowanie kobiet, na które przyzwalała także tradycja kulturowa i praktyki społeczne. Większość kobiet, traktowana w Liberii jako „niższy gatunek”, nie posiadała nawet elementarnej wiedzy dotyczącej ich podstawowych praw. Dlatego, jedną z podstawowych rzeczy było uzmysłowienie im, że gwałt to nie tylko przemoc dokonana na ich ciele, ale także przestępstwo. Wiele kobiet nie uświadamiało sobie tego albo były tak zastraszone, że nie dopuszczały myśli o możliwości ukarania przestępcy. Brakowało im wiedzy, że można zgłosić przestępstwo zgwałcenia na policję. Wydaje się, że najczarniejszy okres w historii Liberii narodził się pod rządami Taylora dlatego warto dodać, że za zbrodnie wojenne odpowiedział on przed Trybunałem w Hadze. Postawiono mu jedenaście zarzutów (dotyczyły skutków wojny domowej w Sierra Leone), w tym zbrodni wojennych, zbrodni przeciw ludzkości, morderstw, gwałtów i prowadzenia wojen rękami dzieci. Jeden ze świadków zeznawał, jak błagał żołnierzy Zjednoczonego Frontu Rewolucyjnego (bojówki terroryzującej Sierra Leone za pieniądze Taylora), by obcięli mu jedyną pozostałą rękę, ale nie zabijali jego dziecka. Inni opowiadali, jak partyzanci Taylora usuwali maczetami płody z brzuchów ciężarnych kobiet i praktykowali kanibalizm. Ktoś widział na własne oczy, jak przywódca Liberii jadł ludzką wątrobę (Stefanicki 30.05.2012).

Choć Taylor został bezpośrednio ukarany za zbrodnie popełnione poza Liberią, także ofiary z jego kraju otrzymały w ten sposób częściowe zadośćuczynienie za wieloletnie krzywdy. Liberia, jaką zastała Johnson-Sirleaf, była $\mathrm{w}$ całkowitej ruinie. W zasadzie wszystko tam wymagało, albo naprawy, albo dopiero wybudowa- 
nia. Kraj pełen kalek, ludzi których wojna upośledziła fizycznie i psychicznie, zdecydował się zaufać idei pokoju powierzonej w ręce dojrzałej kobiety. Zamiast pójść na emeryturę, w wieku 67 lat wystartowała ona w wyborach prezydenckich w 2005 roku, odnosząc niebywałe zwycięstwo.

\section{Kilka faktów biograficznych, czyli kim jest afrykańska „Żelazna dama”?}

W autobiografii zatytułowanej To dziecko będzie wielkie: Wspomnienia $z$ niezwykłego życia pierwszej prezydent Afryki (2009) Johnson-Sirleaf podaje, że tytuł książki wiąże się z prawdziwą historią z jej dzieciństwa. Owej historii Ellen nie może pamiętać, ponieważ wydarzyła się kilka dni po jej narodzinach, jednak zna ją z przekazów swojej matki. Opowieść dotyczy przepowiedni, dzięki której Ellen została naznaczona przez starszego mężczyznę, zgodnie z tradycją składającego życzenia rodzicom z okazji narodzin dziecka, jako wielkie dziecko - przyszła przywódczyni. Jego proroctwo okazało się prawdziwe, jednak oprócz czekających ją wielkich zaszczytów, kryjących się za przywództwem, w przepowiedni brakowało wprowadzenia, czyli tego, jak trudną drogę musi przemierzyć wielkie dziecko, by wielkość swą udowodnić. Biografia Johnson-Sirleaf pokazuje niesamowite koleje losu oraz niezłomność w dążeniu do celu przez „Żelazną damę” Afryki.

Johnson-Sirleaf przyszła na świat w 1938 roku w rodzinie amerykanoliberyjskiej w Monrowii. Tutaj także zaczęła studiować księgowość i ekonomię w College'u of West Africa w Monrowii, lecz nie pozostała w stolicy Liberii przez cały okres edukacji wyższej. Naukę konty- 
nuowała w Stanach Zjednoczonych po wyjściu za mąż za Jamesa Sirleafa, który udzielił jej wsparcia finansowego. Ukończyła studia ekonomiczne na Uniwersytecie w Kolorado, a następnie została przyjęta na Uniwersytet Harvarda, gdzie po trwających między 1969-1971 studiach ekonomicznych, obroniła tytuł magistra administracji publicznej. Jednak, zdecydowała o powrocie do kraju, by tutaj zaangażować się $\mathrm{w}$ działalność polityczną (Sirleaf, Amos Mohammed D. 2009: 26). Wykorzystując wiedzę oraz dyplomy zdobyte za granicą, rozpoczęła karierę polityczną w rządzie prezydenta Williama Talbota. Sprawowała urząd ministra finansów w latach 19721973 oraz ministra finansów w kolejnym rządzie Samuela K. Doe'a, trzymając tekę ministra przez 5 lat, od 1980 roku. Doe doszedł do władzy po zorganizowaniu przewrotu wojskowego w 1980 roku, a jego rządy przyniosły Liberii upadek ekonomiczny i polityczny oraz oznakowanie tego kraju na mapie Afryki jako jednego $\mathrm{z}$ biedniejszych państw tego kontynentu.

Wysuwając swoją kandydaturę w wyborach do Senatu w 1985 roku, Johnson-Sirleaf otwarcie sprzeciwiła się wojskowemu reżimowi, za co została skazana na karę więzienia oraz zmuszona do wyjazdu z kraju. Wkrótce jednak zwolniono ją z więzienia, co $\mathrm{z}$ kolei umożliwiło przyszłej prezydent ucieczkę z ojczyzny do Nairobii, gdzie została wiceprezydentem CitiBanku, a potem Banku Równikowego w Waszyngtonie (Hoogensen \& Solheim 2006: 57). W tym czasie między 1989 a 1999 rokiem w ojczyźnie przyszłej noblistki toczyła się pierwsza wojna domowa, trwająca prawie 10 lat.

Dalszy rozwój kariery prezydent Liberii jest imponujący i rzeczywiście świadczy o zasłużonym przydomku „Żelaznej damy”, jakim ją obdarzono. Od 1992 roku Johnson-Sirleaf pracowała jako Podsekretarz Generalny 
ONZ oraz Administrator Programu NZ ds. Rozwoju Afryki (tamże: 57). Wróciła do Liberii w 1997 roku, aby wziąć udział $\mathrm{w}$ wyborach prezydenckich $\mathrm{z}$ ramienia Partii Pracy. Niestety, wówczas przegrała z Charlesem Taylorem. Zdobyła zaledwie 10 procent głosów. Taylor z łatwością pozbył się swojej przeciwniczki, skazując ją na wygnanie z Liberii i oskarżając o zdradę. Pod jej nieobecność w kraju zachodziły dalsze, przerażające zmiany. Liberia pogrążyła się $w$ wyniszczającej wojnie domowej (1999-2003), zaś po kilku latach odpowiedzialnego za te sytuację Taylora już nie było. Znalazł bezpieczne miejsce na emigracji w Nigerii, zaoferowane mu przez władze tego kraju. Koniec rządów terroru Taylora oznaczał szansę na sięgnięcie po władzę przez Johnson-Sirleaf (Sherman 2010: 311).

Zakończenie wojny domowej w 2003 roku stanowiło zwrot w historii Liberii oraz w osobistej historii przyszłej noblistki. Rzeczywiście, „proroctwo o wielkości”, wygłoszone tuż po narodzeniu Ellen, mogło się spełnić. Johnson-Sirleaf powróciła do polityki, zasiadając w Komisji ds. Reform. Nie zawahała się, by wziąć udział w kolejnych wyborach prezydenckich, odbywających się dwa lata później. „Mama Ellen”, bowiem z takim wizerunkiem przedwyborczym pokazała się swoim rodakom, uzyskała 59 procent głosów, tym samym pokonując rywala - George'a Weaha. Jej zwolennicy utrzymywali, że ma nad nim przewagę $\mathrm{z}$ dwóch powodów: po pierwsze dlatego, że jest świetnie wykształcona (Weah był znanym piłkarzem i gwiazdą futbolu) i po drugie - jest kobietą (Profile: Liberia's „Iron Lady” 23.11.2005). I właśnie kobiety pomogły jej w odniesieniu zwycięstwa. To do nich apelowała i od nich dostała największe poparcie.

„Mama Ellen” jawiła się jako nadzieja, nowa, lecz inna siła, nieugięta kobieta $\mathrm{w}$ świecie zdominowanym 
przez mężczyzn. Symbolicznie, jej zwycięstwo oznaczało początek i odnowę po apokalipsie, jaką pozostawiła tyrania. Znamienny jest fakt, że na jej zaprzysiężeniu obecne były prominentne postaci kobiece ze świat polityki: Condoleezza Rice oraz Hillary Clinton. Wybrana na prezydenta Liberii, dojrzała i wizjonerska Ellen, zapowiadała „nową erę demokracji” oraz „całkowite zerwanie z przeszłością" (Sheeler 2011: 1359). Objęcie władzy przez przyszłą noblistkę, zapowiadającą się na niezachwianą orędowniczkę idei pokoju, stanowiło szansę na reformy i uregulowanie sytuacji Liberyjek.

\section{„Mama Ellen” noblistką 2011 - kontrowersje wokół Pokojowej Nagrody}

Johnson-Sirleaf nie tylko ze względu na swój wiek mogła posługiwać się licznymi odwołaniami do roli matki w społeczeństwie. Matka, jako kulturowa figura, najbardziej pierwotna ze względu na więź łączącą ją $\mathrm{z}$ potomstwem, także $\mathrm{w}$ kulturze patriarchalnej mogła przemówić do świadomości społecznej, przynajmniej jej kobiecej części. Choć także mężczyźni głosowali na „Mamę Ellen”. Chciała wprowadzić nową, matczyną wrażliwość oraz, zamiast czystej kalkulacji, także emocje, których brakowało w trakcie rządów „bezwzględnego rozumu".

W opinii pani prezydent, jej droga do szczytów władzy nie była usłana różami, a raczej nieustanną konkurencją z mężczyznami, oznaczającą ciągłe udowadnianie, że kobieta bezwzględnie musi być lepsza, ale też nie może rezygnować ze zdobycia ich szacunku (mk 7.10.2011). Swoją postawą demonstrowała szczególną 
życzliwość i zrozumienie dla pozbawionych praw kobiet w „kraju wolności”. Nie kryła, że docenia kobiety, które jej zdaniem w porównaniu z mężczyznami, mają silniejsze poczucie obowiązku, są bardziej zaangażowane, ciężej pracują, ale też są uczciwsze (Carvajal 8.03.2012). $\mathrm{Z}$ własnego doświadczenia $\mathrm{w}$ pracy na wysokich stanowiskach wywnioskowała również, że za skandalami, korupcjami oraz fałszerstwami stali właśnie mężczyźni i to z nimi musiała przez lata współpracować tak, by ani nie utonąć, ani nie dać się złapać $\mathrm{w}$ tę sieć pełną nie tylko „wielkich ryb”, ale i wielkich politycznych afer. Johnson-Sirleaf nie stroni od tego typu stwierdzeń, udzielając wywiadów czy też w prasie, komentując położenie kobiet w polityce.

Wydaje się, że dla Liberii oznaczała „promyk nadziei”, zaś dla jej zwolenniczek nawet „zbawienie”, co dostrzegł Komitet, rozstrzygający o przyznaniu Pokojowej Nagrody Nobla. Takim światem pokrytym „opleśniałą korą" była właśnie jej ojczyzna. Komitet Noblowski w Oslo, który uzasadnił przyznanie nagrody trzem kobietom: Johnson-Sirleaf, jej rodaczce Leymah Gbowee oraz Jemence Tawakkul Karman, podkreślając ich zasługi $\mathrm{w}$ walce bez przemocy na rzecz bezpieczeństwa i praw kobiet do pełnego udziału $\mathrm{w}$ procesie budowy pokoju. W przypadku najstarszej z nich, doceniono zwycięstwo prezydent Liberii i jej działania na rzecz kobiet, a także promowanie ich na najwyższych stanowiskach w Liberii oraz dawanie tym przykładu innym krajom Afryki. Podkreślono też ,jej działania jako szefowej państwa na rzecz odbudowy kraju po zakończonej w 2003 roku krwawej wojny domowej" (mk 7.10.2011).

Przyznanie Johnson-Sirleaf Pokojowej Nagrody Nobla wzbudziło wiele kontrowersji oraz skrajnych opinii na całym świecie. Ich źródło leży w niejednoznacznej 
ocenie rządów oraz kariery politycznej przywódczyniLiberyjki. Jedno jej oblicze odkrywa żywiołową i pracowitą kobietę, posiadającą doskonałe wykształcenie, a także znakomite doświadczenie na stanowiskach w światowych instytucjach, ale mimo to mającą łatwy i bezpośredni kontakt z prostymi mieszkańcami swego kraju. Prezydent-kobieta jest wychwalana na Zachodzie i postrzegana jako gwarant stabilizacji w Liberii, a tym samym w regionie. Rząd amerykański nieco dopomógł w utrzymaniu tej sytuacji, przeznaczając środki finansowe na armię liberyjską, czyniąc z niej „najlepiej wyszkoloną i zorganizowaną siłą militarną w regionie" (Piekarska 2011).

Wśród innych docenianych na arenie międzynarodowej dokonań noblistki zalicza się udane reformy fiskalne, dzięki którym Międzynarodowy Fundusz Walutowy i Bank Światowy umorzyły wynoszący 4,6 miliardy USD dług Liberii. Z danych na temat wysokości budżetu Liberii wynika, że został zwiększony z $80 \mathrm{mi}-$ lionów USD w roku 2005, do 350 milionów w 2011. Prezydent postarała się też o naprawę infrastruktury drogowej oraz zapewnienie, by coraz większa ilości ludzi miała dostęp do bieżącej wody (Piekarska 2011). Liczne choroby trapiące ten kraj wynikają właśnie z braku tego podstawowego dobra.

Okazuje się, że drugie oblicze noblistki, raczej mało eksponowane, czy może nawet ukrywane przed wyborami, ściśle wiąże się, zarówno z dawnymi decyzjami politycznymi prezydent, jak i jej poczynaniami na tym stanowisku, zwłaszcza tymi, które dotyczą spełnienia obietnic wyborczych związanych z nową jakością władzy. Jednym z priorytetów, jakimi miała się kierować nowa prezydent, była walka z wszechobecną korupcją. Jednakże pomimo tych zapowiedzi Liberyjczycy wciąż narzeka- 
ją na korupcję w kraju, wytykając pani prezydent nieskuteczność oraz jej osobiste „dokonania” na tym polu, które omawiam poniżej (Wojna noblistek w Liberii 2012).

Prezydent Liberii spotkała się z serią oskarżeń rzucanych $\mathrm{w}$ jej stronę, głównie z powodu niedostatecznej skuteczności i wybiórczości w działaniach. Oskarżono ją również o nepotyzm, po tym jak m.in. mianowała na pewien czas jednego ze swych synów dyrektorem Narodowej Agencji Bezpieczeństwa, a na ministra spraw wewnętrznych brata. Inne zarzuty dotyczą udzielenia przez Johnson-Sirleaf wsparcia finansowego dla działań Charlesa Taylora. Nie mogło też ujść krytyce, że część członków rządu Johnson-Sirleaf to wysoko postawieni urzędnicy z okresu rządów Taylora i Samuela Doe. Wypomina się jej ponadto, że kiedy kandydowała pierwszych w wyborach prezydenckich, zapowiadała, iż jedna kadencja jej wystarczy. Wiadomo, że skutecznie postarała się o reelekcję, bowiem w 2011 roku w kolejnych wyborach prezydenckich zwyciężyła $\mathrm{z}$ wynikiem 90,7 procent głosów. Pokonała Winstona Tubmana w wyborach uznanych przez międzynarodowych obserwatorów za przejrzyste i wolne (mimo zarzutów opozycji).

0 sile rzucających się cieniem na wizerunku noblistki zarzutów przesądziły działania Leymah Gbowee, przewodniczącej Komisji Pokoju i Pojednania. W opinii tej noblistki, która wraz z prezydent Liberii odbierała nagrodę: „Johnson-Sirleaf jest jak wszyscy inni 'Kongijczycy'. Dba tylko o swoich i swoimi się otacza, swoimi obsadza wszystkie najważniejsze stanowiska, o innych nie dba". Wypowiadając te słowa przypieczętowała swoją rezygnację $\mathrm{z}$ przewodniczenia Komisji Pokoju i Pojednania (PAP 10.10.2012). Wartym wyjaśnienia jest określenie „Kongijczycy”, odnoszące się do pani prezydent: 
Johnson-Sirleaf wywodzi się z potomków czarnoskórych niewolników z USA, którzy, uzyskawszy wolność dzięki pomocy ruchu abolicjonistów, wrócili w połowie XIX wieku do Afryki i osiedlili się w wykupionej Liberii. W Afryce dawni niewolnicy, przezywani tu „Kongijczykami”, błyskawicznie przekształcili się w kastę rządzącą, dyskryminującą miejscowe ludy. Konflikt między obiema grupami społecznymi stał się przyczyną wojskowego zamachu stanu w 1980 r. (dopiero wtedy tubylcy przejęli władzę od „osadników”) i wybuchu wojny domowej w 1989 r. (Wojna noblistek $w$ Liberii 2012).

Surowa krytyka wymierzona w noblistkę to również próba rozsądzenia czy słusznie otrzymała Pokojową Nagrodę Nobla. Jednym z artykułów o takim charakterze jest Sirleaf-Johnson nie jest Mandelq autorstwa Wojciecha Jagielskiego. Autor twierdzi, że porównywanie urzędującej prezydent Liberii do Nelsona Mandeli to nieporozumienia i przesada, które jednak są częste w opiniach na jej temat na Zachodzie. Uznaje on, że Johnson-Sirleaf nie może poszczycić się zasługami, za które można uhonorować najbardziej prestiżową nagrodą za osiągnięcia w działalności na rzecz pokoju. Na jednej szali znajdują się głosy negatywne, stawiające pod znakiem zapytania celowość przyznania jej tego odznaczenia. Liberyjka otrzymała je tuż przed wyborami, ubiegając się o reelekcję. Opozycja uznała, że był to przejaw mieszania się w wewnętrzne sprawy kraju oraz niezaprzeczalny element, który przechylił szalę zwycięstwa na korzyść Johnson-Sirleaf (Sirleaf does not deserve). Na drugiej natomiast należy położyć pozytywne reakcje po rozdaniu Pokojowego Nobla 2011 ze strony m.in.: Angeli Merkel, Jose Manuela Barroso, czy też Lecha Wałęsy (Staniecki 2011). Oczywiście nie są to głosy pochodzące „z głębi kraju”, lecz oficjalne, wygłoszone na arenie międzynaro- 
dowej. Jednoznaczna ocena jest niemożliwa, zwłaszcza jeśli weźmie się pod uwagę zarówno historyczne znaczenie Nobla dla kobiet oraz zmiany, jakie zaszły w Liberii kiedy urząd prezydenta sprawuje „Mama Ellen”.

\section{Idolka Afrykanek}

Jak pokazała nadal napięta sytuacja polityczna, ekonomiczna oraz społeczna w Liberii, nie wszystko ułożyło się po myśli pani prezydent. Przed Johnson-Sirleaf po reelekcji pojawił się kolejny etap sprawowania rządów. Na razie złożyła wyjaśnienia przed Komisją Prawdy i Pojednania, powołaną po raz pierwszy za jej prezydentury, w związku z tym, że będąc przez lata ministrem finansów, zbyt aktywnie wspierała zbrodniarzy wojennych. Jednak stanowisko Johnson-Sirleaf jest nieprzejednane odpiera te zarzuty, tłumacząc się tym, że o ile współpracowała z dyktatorami, to jednak nie po to, by wchodzić z nimi w układy pojednawcze, lecz walcząc o słuszną sprawę. Przyznała natomiast, że faktycznie wspierała finansowo Taylora, lecz trwało to krótko. Jak się okazuje, mimo, że Komisja Prawdy uznała, że Johnson-Sirleaf przez 30 lat nie będzie mogła pełnić żadnego publicznego urzędu, sama oskarżona zignorowała decyzję Komisji (Stefanicki 12.01.2011). Jak wiadomo, ponownie sprawuje władzę najwyższą w swojej ojczyźnie.

Wydaje się jednak, że Johnson-Sirleaf już zapisała się jako najlepszy przywódca, jakiego miał „kraj wolnych ludzi”. Na pewno jej prezydentura zapewnia spokój i stabilizację w tym niespokojnym regionie afrykańskim. Jej kontakty z państwami zachodnimi oraz organizacjami międzynarodowymi także zasługują na pochwałę. Poza 
tym otrzymanie przez nią nagrody Nobla nie było kwestią przypadku, tylko uznaniem dla podjęcia przez nią próby naprawienia państwa.

Pierwsza republika w Afryce na kartach historii zostanie zapamiętana też jako pierwszy kraj afrykański funkcjonujący pod przywództwem kobiety prezydenta. Będąc najpotężniejszą kobietą $\mathrm{w}$ zmaskulinizowanej Afryce, Johnson-Sirleaf jest również idolką Afrykanek, poszukujących autorytetu „o kobiecych rysach”. „Mama Ellen” stanowi jego ucieleśnienie, przede wszystkim dlatego, że do wszystkiego dążyła o własnych siłach. W Liberii można spotkać transparenty wykonane przez kobiety z napisami: „Mamo Ellen Johnson Sirleaf kochamy cię za to, co robisz dla młodych dziewcząt w naszym kraju" (Bergner 2011).

Jej sytuacja rodzinna, czyli z jednej strony sparaliżowany wylewem ojciec, oraz z drugiej - mąż-despota, z którym się rozwiodła, w żadnym stopniu nie ułatwiła jej dojścia do władzy. W jednym z artykułów poświęconych noblistce można znaleźć fragmenty dotyczące przemocy, jakiej doświadczała od męża. Chociażby karanie jej za pracę poza domem, czy wspomnienie o udaremnionej próbie jej zabójstwa przez małżonka (Bergner 2011). Zatem, hartowanie ducha i potępienie dla przejawów agresji, szczególnie w stosunku do kobiet, znajdujących się w okresie wojny domowej w jeszcze gorszym położeniu od samej Ellen, pomogło jej w wypracowaniu postawy osoby niezłomnej, odważnej i bezkompromisowej. Nawet, jeśli nie jest kryształowa, dokonała przełomowych osiągnięć na polu politycznym, ekonomicznym oraz społecznym.

Johnson-Sirleaf musiała także zrezygnować z roli przykładnej matki, kiedy swoich synów oddała pod opiekę krewnych a sama studiowała w Stanach Zjednoczonych, 
przebywając tam na stypendium. Doświadczona przemocą domową oraz wyrokiem skazującym ją na pobyt w więzieniu, w którym tylko cudem uniknęła gwałtu, Johnson-Sirleaf zaznała wielu upokorzeń, nim sięgnęła po urząd prezydenta. Zatem, to właśnie w związku z historycznymi osiągnięciami znalazła się noblistka 2011 - „Mama Ellen” - w pracy autorstwa Kathleen Kuiper poświęconej stu najbardziej wpływowym kobietom wszechczasów The 100 Most Influential Women Of All Time (seria Brittanica Guide, 2009). Filmowym zapisem poczynań pierwszej w historii kobiety prezydent w Afryce jest film dokumentalny pt. Żelazne damy Afryki w reżyserii Siatty Scott Johnson i Daniela Junge'a z 2008 roku. Wyraźnie w nim widać kobiece rysy Liberii.

Johnson-Sirleaf pomogła spełnić swoistą feministyczną fantazję o zajmowaniu najwyższego stanowiska przez kobietę w kraju afrykańskim. Na pewno nie zdołała rozwiązać wielu problemów nękających ukochaną przez nią Liberię, na pewno nie udało jej się to, czego oczekiwała od siebie po pierwszej kadencji, ale w liberyjskim gąszczu biedy i bezprawia zapanował okres bez wojny i całkowitego przyzwolenia na gwałcenie podstawowych praw człowieka. Nadal wiele od niej zależy i z pewnością nie raz odczuła na własnych barkach ciężar rządzenia. Dane statystyczne mogą przerażać, jeśli spojrzy się na ilość osób bez pracy czy tez bez edukacji, lecz podwaliny pod zbudowanie nowego społeczeństwa zostały przez Johnson-Sirleaf przygotowane, a siła tkwiąca w przywódczyni - matce narodu, wykorzystana z sukcesem. „Mama Ellen” nadal ma realny wpływ na kształtowanie historii Liberii, zaś jej autobiografia mogłaby być uzupełniona o kolejną część, by udowodnić jak „wielkie dziecko" przyszło na świat w 1938 roku. 


\section{Bibliografia}

Hoogensen G., Solheim B. O., 2006. Women in Power: World Leaders Since 1960, Greenwood Publishing Group, Westport.

Kuiper K., 2009. The 100 Most Influential Women of All Time, The Rosen Publishing Group.

Njorge W.N., Wamue-Ngare G., 2011. Gender Paradigmschft within the Family Structure in Kiambu, Kenya, "African Yournal of Social Sciences", Vol. 1.3, 10-20.

Sheeler H., 2011. Sirleaf, Ellen Johnson (President of Liberia) [w:] Mary Zeiss Stange, Carol K. Oyster, Jane E. Sloan (red.), Encyclopedia of Women in Today's World, Tom 1. SAGE, 1358-1359.

Sherman F., 2010. Liberia: The Land, Its People, History and Culture. Godfrey, Mwakikagile.

Sirleaf Amos Mohammed D., 2009. Visionary Liberia Leader: Ellen Johnson-Sirleaf, Author House, Bloomington.

Woodson Carter G., 2008. Negro Makers of History, Wildside Press LLC.

\section{Źródła internetowe}

Bergner D., 2011-10-22. An Uncompromising Woman. "The New York Times", http://www.nytimes.com/2010/10/24/magazine/ 24sirleaf-t.html?pagewanted=all (26.11.2012)

Carvajal D., 2012-03-08. Liberia: kraj silnych kobiet. Przeł. Katarzyna Ziomek. "The International Herald Tribune", http://fakty.interia.pl/ news/liberia-kraj-silnych-kobiet,1449165 (23.11.2012)

Jagielski W., 2011-10-08. Sirleaf-Johnson nie jest Mandelq. „Gazeta Wyborcza", http://wyborcza.pl/1,76842,10431848,Sirleaf_Johnson_ nie_jest_Mandela.html (24.11.2012)

mk, 2011-10-07. Ellen Johnson-Sirleaf - pierwsza kobieta prezydent w Afryce. PAP, http://www.tvn24.pl/ellen-johnson-sirleaf-pierwszakobieta-prezydent-w-afryce,186708,s.html (23.11.2012)

Wojna noblistek $w$ Liberii: Gebowee oskarża Johnson-Sirleaf o korupcje i nepotyzm. 2012-10-10. PAP, http://www.polskatimes.pl/ artykul/674683,wojna-noblistek-w-liberii-gbowee-oskarzajohnson-sirleaf-o,2,id,t,sa.html (23.11.2012)

Piekarska M., 2011-12-09. Dokąd zmierza Liberia? „Gazeta Finansowa Online", http://www.gf24.pl/6626/dokad-zmierza-liberia (23.11.2012) 
Profile: Liberia's "Iron Lady". 2005-11-23. BBC News, http:// news.bbc.co.uk/2/hi/africa/4395978.stm (23.11.2012)

Sirleaf-Johnson E., 2009-05-15. This Child Will Be Great "New York Times", http://www.nytimes.com/2009/05/17/books/chapterthis-child-will-be-great.html?_r=0, (22.11.2012)

Sirleaf does not deserve Nobel Prize, say Weah, Tubman. 2011-10-07. Reuters, http://www.reuters.com/article/2011/10/07/us-nobelliberia-idUSTRE7966HW20111007 (22.11.2012)

Stefanicki R., 2012-10-12. Dwie Liberyjki: Laureatki pokojowego Nobla sprzed roku, toczq ze sobq wojnę. „Gazeta Wyborcza”, http:// wyborcza.pl/2029020,75477,12654104.html (23.12.2012)

Stefanicki R., 2012-05-30. 50 lat dla byłego prezydenta Liberii. „Gazeta Wyborcza", http://m.wyborcza.pl/wyborcza/1,105226,11828419, 50_lat_wiezienia_dla_bylego_prezydenta_Liberii.html (09.11.2012) Szaniecki M., 2011-10-07. „Kobiety zostały docenione”. Entuzjastyczne komentarze po Noblu. „Gazeta Wyborcza”, http://wyborcza.pl/ $1,76842,10428588$,_Kobiety_zostaly_docenione_Entuzjastyczne_ komentarze.html (24.11.2012) 